\title{
Society seen as a victim - how it may affect criminal law
}

\author{
ELŻBIETA HRYNIEWICZ-LACH \\ ORCID: 0000-0001-6098-7087 \\ Department of Criminal Law \\ Faculty of Law and Administration \\ Adam Mickiewicz University in Poznań, Poland
}

\section{The role of society in cases of crime in European law}

\section{1. 'Victim' in the law of the European Union}

Criminal law in the European Union can be regulated by directives implemented into the legal system of member states. One of the EU directives, $\mathrm{Nr} 29$ from 25.10.2012 establishes minimum standards on the rights, support and protection of victims of crime. ${ }^{1}$ The purpose of this directive is to ensure that victims of crime receive appropriate information, support and protection and are able to participate in criminal proceedings (art. 1). The victim, for the purposes of the directive, was defined as a natural person who has suffered harm, including physical, mental or emotional harm or economic loss directly caused by a criminal offence and family members of a person whose death was directly caused by a criminal offence and who have suffered harm as a result of that person's death (art. 2.1.a).

1 Directive 2012/29/EU of the European Parliament and of the Council of 25 October 2012 establishing minimum standards on the rights, support and protection of victims of crime, and replacing Council Framework Decision 2001/220/JHA (OJ L 315/57, 14.11.2012). 
It was also noticed in the preamble of the directive that crime is a wrong against society, as well as violation of the individual rights of victims (p. 9) and that terrorist attacks are intended to harm society (p. 16). Nonetheless the victim, as a subject of rights in criminal proceeding, is understood as an individual victim. Also Directive 2004/80/EC of 29.4.2004, relating to compensation to crime victims and setting up a system of cooperation to facilitate access to compensation to victims of crimes in cross-border situations, relates to individual victims. ${ }^{2}$

\section{2. 'Victim' in recommendations of the Council of Europe}

The victim's support is also an object of interest in the recommendations of the Council of Europe. In recommendation Rec (2006) 8 of the Committee of Ministers to member states on assistance to crime victims, ${ }^{3}$ a victim is described as "natural person who has suffered harm, including physical or mental injury, emotional suffering or economic loss, caused by acts or omissions that are in violation of the criminal law of a member state. The term victim included also, where appropriate, the immediate family or dependants of the direct victim" (p. 1.1). Recommendation refers to protection and support of victims which should be guaranteed by the state. Such support may be delivered, among others, by raising public awareness of the victim's needs, encouraging understanding and recognition of the effects of crime in order to prevent secondary victimisation $^{4}$ and to facilitate the rehabilitation of victims (p. 16.1). Society is seen mainly as personnel coming into contact with victims, which should be taught how to minimalise the impact of crime on them.

Society in COE recommendations is also seen as "the public." In accordance with recommendation nr R (83) 7 of the Committee of Ministers to Member States on participation of the public in crime policy, ${ }^{5}$ govern-

2 Council Directive 2004/80/EC of 29 April 2004 relating to compensation to crime victims (OJ L 261/15 6.8.2004).

3 Adopted by the Committee of Ministers on 14 June 2006 at the 967 th meeting of the Ministers' Deputies.

4 Defined as the victimisation that occurs not as a direct result of the criminal act but through the response of institutions and individuals to the victim (p. 1.3).

5 Adopted by the Committee of Ministers on 23 June 1983 at the 361 st meeting of the Ministers' Deputies. 
ments of member states should promote participation of the public in the drawing up and implementation of crime policy aimed at prevention of crime, use of alternatives to custodial sentences and provision of assistance to victims. However, the role of society is seen mainly in participating in advisory committees and public debates on criminal policy enabling society to recognise the "fundamental role it should play in implementing a policy for the prevention of crime and the social reintegration of offenders, notably by involving it in alternatives to custodial sentences and in assistance to victims." Society is then seen not as a victim but as a body realising state crime policy in preventing offences from being committed and assisting individual victims both during and after perpetration of an offence (p. D.25).

Some regard to society's interest in criminal reaction was made in recommendation nr R (99) 19 on mediation in criminal matters. ${ }^{6}$ According to point V. 22, mediators should be recruited from all sections of society and should generally possess a good understanding of local cultures and communities. The reason for this may be found in an explanatory memorandum to the recommendation, where it was indicated that mediators should preferably possess a good all-round knowledge, in particular concerning the local environment in which they are active. ${ }^{7}$ Having knowledge of the local environment, mediators may be able to understand the motives of individual victim and offender as mediating parties, and feel the sense of justice in (local) society, important to restore it in the mediation process. These aspects enable mediators to respect interests of the individual victim and offender in a broader context of the impact of mediation results on the environment. As mentioned in an explanatory memorandum to the recommendation: "socially constructive solutions are of benefit to all parties concerned. The conciliatory nature of mediation can assist the criminal justice system in fulfilling one of its fundamental objectives, namely contributing to a peaceful and safe society by restoring balance and social peace after a crime has been committed." 8 Society is

6 Adopted by the Committee of Ministers of the Council of Europe on 15 September 1999.

7 Explanatory memorandum to the recommendation, pp. 22-23.

8 Explanatory memorandum to the recommendation, pp. 12-13. 
then seen as an entity disturbed by conflict resulting from crime and therefore interested in conflict resolution.

Recommendation Rec (2017) 3 on the European rules on community sanctions and measures, ${ }^{9}$ declares that its rules are intended to establish a set of standards to help national legislators, deciding and implementing authorities and practitioners, to provide just and effective use of community sanctions and measures. Such standards shall include the need to protect society, maintain legal order and support social rehabilitation, as well as to support offenders in making reparations for the harm they caused. This statement shows that society may also be seen as the beneficent of state reaction to a crime, which has its own interests in protection and maintaining legal order. In the explanatory memorandum to the recommendation, provided by the Council of Europe, it was pointed out that an offence is harm done to the victim and to society. Therefore society also has an interest in appropriate criminal reaction. This interest, described as the public interest, involves providing community safety and upholding the legal order in society, in a way that respects fundamental rights of suspects and offenders. ${ }^{10}$ It is believed that at least in some cases such public interest can be realised by sanctions and measures which do not isolate offenders, but leave them in society and enable social re-integration by helping them to recognise their responsibility for the offence and develop a sense of responsibility towards the community. ${ }^{11}$ Rehabilitation of offenders should be possible by community sanctions and measures like, among others, community service (i.e. unpaid work on behalf of the community) as a criminal measure or condition imposed in case of suspension of enforcement of the sentence of imprisonment. Society is then seen as a victim of crime, victimised in a different way than the individual victim but still desiring an appropriate criminal reaction to satisfy its safety and justice needs.

9 Adopted by the Committee of Ministers on 22 March 2017 at the 1282 nd meeting of the Ministers' Deputies.

10 Explanatory memorandum to the recommendation, pp. 5, 11.

11 Explanatory memorandum to the recommendation, p. 12. 


\section{3. "Victim' in the United Nations" declaration}

The United Nations also makes reference to victims of crime. In the Declaration of basic principles of justice for victims of crime and abuse of power from 29 November 1985, victims are defined as "persons who, individually or collectively, have suffered harm, including physical or mental injury, emotional suffering, economic loss or substantial impairment of their fundamental rights, through acts or omissions that are in violation of criminal laws operative within member states, including those laws proscribing criminal abuse of power" (A.1). Collective victim should be basically understood, in the context of the whole document, as a group of direct victims, so this concept does not include society, neither a large, nor a local one (community). The community efforts and participation of the public refer in the declaration to crime prevention (p. 4b) and to social assistance of individual victims (p. 14). However, the declaration indicates the need for restitution to all of society as well as to the local community in cases of substantial harm to the environment, which should include, as far as possible, restoration of the environment, reconstruction of the infrastructure, replacement of community facilities and reimbursement of the expenses of relocation, whenever such harm results in the dislocation of a community (p. 10). This aspect of restoring justice shows that society can be regarded as an entity suffering at least certain material consequences of crimes committed against common goods.

The above mentioned regulations of European law supporting victims of crime focus primarily on individual victims and their rights and claims within criminal proceeding. Society is most often seen as a body realising state prevention policy or supporting individual victims of crimes in ways that enable to reduce risk of secondary or repeat victimisation. In legal acts which recognise society as a victim of crime, it is noticed that society may also suffer certain consequences of crime but in a different way than an individual victim, which requires at least a partly different attitude and instruments to satisfy its interests in restoring a sense of security and justice. Such a concept of society as a victim of crime has been an object of interest in legal doctrine which defined society as a potential, normative or secondary victim. 


\section{Society as a victim of crime}

\subsection{Potential victim}

Crime in the history of criminal law has never been a case solely between offender and individual victim. There was always a group of other people interested in its outcomes: tribe, family, neighbours or community specified in different ways, whose members sympathise and identify with the individual victim of a certain crime or their family members. ${ }^{12}$ These people may feel frightened, angered or disturbed in other ways by information about a crime, because they predict that in the future they or their family members may become individual victims of a similar offence. Not all members of a certain community will be disturbed by information about a crime committed in their community, but at least some of them may express those feelings. Not all members of a certain community will also be at relatively high risk of being individual victims of a similar crime in the future, but most often such risk cannot be generally excluded. This probability led German criminologist Kurt Seelmann to describe society as a potential victim of crime. The term "potential victim" includes both of the above mentioned possibilities: "potential" understood as "it is not possible to exclude that at least some members of the community were disturbed by the information about a crime," as well as "it is possible that at least some members of the community may be individual victims of crime in the future." Nowadays, thanks to mass media, not only can the local community be informed and concerned about a crime but the whole of society as well, a concept of potential victim can be referred to the whole of society. ${ }^{13}$ As a consequence, the whole of society may have an interest in an appropriate reaction to crime.

12 J.Ph. Reemtsma, Das Recht des Opfers auf die Bestrafung des Täters - als Problem. Schriften der Juristischen Studiengesellschaft Regensburg, München 1999, p. 5; G.P. Fletcher, "Der Platz des Opfers in einer Vergeltungstheorie," [in:] Die Stellung des Opfers im Strafrechtssystem. Neue Entwicklungen in Deutschland und in den USA, eds. B. Schünemann, M.D. Dubber, Köln-München 2000, pp. 78-79.

13 K. Seelmann, "Paradoxien der Opferorientierung im Strafrecht," Juristen Zeitung 1989, p. 671. See also: W. Schmidt-Hieber, "Ausgleich statt Geldstrafe," Neue Juristische Wochenschrift 1992, pp. 2001-2002. 


\subsection{Normative victim}

Even if society is concerned about a crime committed, it is disturbed in a fundamentally different way than an individual victim. It lacks suffering or direct material or immaterial damage. Its values affected by the offence are most often abstract like "justice," "public order" or "public health" and if they are more concrete, the effects of crime are more distant and therefore seem to be less real, like pollution of the natural environment. These aspects caused even naming crimes in which no individual victim was hurt in a direct way, "crimes without victims."14 Nonetheless, criminal law is a part of public law and as such represents not only the interests of individuals but also protects abstract values in society's interests. The perception of society as an entity which is not directly hurt by a certain crime but, in case of any crime, bears its negative effects and creates a reason to apply criminal law, became the basis for the concept that society is a victim of (any) crime in a normative and not empirical sense. ${ }^{15}$

\subsection{Secondary victim}

The fact that society is disturbed in a different way than an individual victim does not mean that it cannot be satisfied with the offender's voluntary activity or instruments of criminal law that are aimed at restoring (a sense of) justice with reference to the victim's needs. Restorative justice based on the concept of a victim-offender-settlement, recognises the important role of community in solution of conflicts resulting from crime. Howard Zehr, one of the restorative justice advocates, emphasises that "community members have needs arising from crime and they have roles to play. [...] Communities are impacted by crime and in many cases should be considered stakeholders as secondary victims." ${ }^{16} \mathrm{H}$. Zehr underlines in this way a difference between community and society, assigning tasks in conflict solution only to micro-communities of place (where people still live nearby and interact with each other) or networks of relationships (that

14 M. Smarzewski, Podmiot bierny przestępstwa na tle włoskiego prawa karnego, Lublin 2013, pp. 14, 23-25, 93-100.

15 W. Hassemer, "Warum und zu welchem Ende strafen wir?" Zeitschrift für Rechtspolitik 1997, p. 318.

16 H. Zehr, A. Gohar, The little book of restorative justice, 2003. https://www.unicef.org/tdad/ littlebookrjpakaf.pdf (accessed: 18.11.2019), p. 16. 
may not be geographically defined) that are directly affected by an offence but often neglected by "state justice." 17 Since traditional communities have mostly eroded in western society (and those that still exist, like in Polish traditional villages, mostly do not engage themselves in restoring justice in criminal cases ${ }^{18}$ ), the author proposes to identify as community in the sense of restorative justice, those who care about the individual victim and offender or about the offence and who can involve in the process of "putting things right" out of the state criminal system. ${ }^{19}$ According to H. Zehr's concept of restorative justice, not the whole of society may be seen as a secondary victim, but only a part of it that is particularly interested in conflict resolution, because it has a direct impact on their personal relations or close (local, work) environment.

Regarding the victim of crime not only as an individual victim but also a potential, normative or secondary victim is an important aspect of criminal reaction. It allows us to see that criminal response not only has an individual dimension, but is a wider problem involving the interests of the local community or even the whole of society. Since the individual victim is victimised in a different way than society, both subjects - in accordance with the abovementioned COE recommendations and ONU-declaration - need to be addressed in response to crime, it is important to see how the interests of this subject can be defined and satisfied with the instruments of criminal law.

\section{Interests of society in criminal law \\ 3.1. Society's interest in criminal law (prevention and compensation)}

In accordance with the concept of German criminal law professor Claus Roxin changes in society's expectations regarding responses to

17 Ibid., pp. 26-27.

18 See: P. Chlebowicz, Samosad we Włodowie. Studium przypadku, Olsztyn 2017, pp. 57-59; with reference to J. Czapiński; J. Czapska, Bezpieczeństwo obywateli. Studium z zakresu polityki prawa, Kraków 2004, p. 103; A. Kossowska, "Sytuacyjne zapobieganie przestępczości," Archiwum Kryminologii 20, 1994, pp. 14-15.

19 H. Zehr, A. Gohar, op. cit., p. 26. 
crime are the expression of development of certain society's needs. In Germany after the times of national socialism, it was important to restore justice with 'just punishment', which means referring the penalty to the seriousness of the offence determined not by the national-socialist sense of justice, but by protected values and the way they were violated. Once criminal law reached this level in the 1970s, criminal reaction transformed to one that would meet society's further needs, like protection of society and social re-integration of the offender with educational measures and re-socialisation. Significant costs required to ensure proper conditions for rehabilitation and, at the same time, the high percentage of recidivism found in the 1980s showed disadvantages of the rehabilitation system. ${ }^{20}$ These factors reduced the importance of individual prevention and drew attention to the impact of punishment on society at large or on a certain community (deterrence and integration), until it was established that also this aspect is complex and difficult to verify in an empirical way. ${ }^{21}$ Therefore, a wide-ranging analysis was carried out of legal regulations applied in other countries with regard to redressing damage caused by crime. ${ }^{22}$ Its aim was to find new instruments of criminal reaction that could restore justice at least to some extent by satisfying the individual victim and society's needs resulting from committed crime.

The above presented changes in German criminal law — that refer to common development of criminal law - were not, however, a kind of transformation from one concept of criminal law to another, but based on assigning special importance to different aspects of criminal response. In fact, reaction to crime includes all the mentioned aspects, because they jointly allow to achieve the aims of criminal law — restoring (a sense of) justice and security. Punishment, in the form of financial sanction or deprivation of liberty or certain rights and freedoms, restores a sense of justice

${ }^{20}$ C. Roxin, "Nowe kierunki polityki kryminalnej," Przeglad Prawa Karnego 1990, no. 4, pp. 94, 97; H. Marquardt, "O teoretycznym i praktycznym znaczeniu celów kary w zachodnio-niemieckim prawie karnym," [in:] Teoretyczne problemy odpowiedzialności karnej w polskim oraz niemieckim prawie karnym. Materiaty Polsko-Niemieckiego Sympozjum Prawa Karnego, ed. T. Kaczmarek, Karpacz 1990, p. 124.

${ }^{21}$ H. Marquardt, op. cit., pp. 122-124; C. Roxin, op. cit., pp. 97-101.

22 See: Neue Wege der Wiedergutmachung im Strafrecht, eds. A. Eser, G. Kaiser, K. Madlener, Freiburg-Breisgau 1992; A. Eser, S. Walther, Wiedergutmachung im Kriminalstrafrecht. Internationale Perspektiven, vol. 1-3, Freiburg-Breisgau 1996-2001. 
by expressing disapproval and condemnation by authorities and society represented by those authorities. ${ }^{23}$ Punishment has a symbolic character, based on moral compensation to society and to individual victims, which creates its justification in retributive justice. ${ }^{24}$ Satisfaction by restored justice can also be achieved in another way, by material compensation (restitution, indemnity) or moral compensation in case of the offender's efforts to meet the victim's needs resulting from crime. Moral compensation of the individual victim can have the form of an apology, financial or personal benefits, while society can be satisfied with social work or payment of a certain sum for social purpose (called in German literature: symbolic compensation ${ }^{25}$ ). This aspect of moral compensation implements the concept of restorative justice. Next to restoring a sense of justice in society and by individual victims, exists another aim of criminal law - restoring a sense of security by protecting the individual victim and other members of society against their victimisation in the future. The concept of preventive justice was initially based on efforts to influence the identified offender or society (seen as a group of potential offenders) in a way that would discourage them from committing crimes. Nowadays, more and more attention is paid to protecting the individual victim and society seen as a group of potential victims. This aspect of crime prevention includes not only a wide range of preventive activity going beyond criminal law ${ }^{26}$ (like situational prevention through design ${ }^{27}$ ), but also just and appropriate reaction to crime in order to show that victims are treated with respect

23 J. Feinberg, "Funkcja ekspresyjna kary kryminalnej,“ Ius et Lex 2006, no. 1, pp. 219-224; Th. Weigend, "Die Strafe für das Opfer?”- Z Zur Renaissance des Genugtuungsgedankens im Straf- und Strafverfahrensrecht, "Zeitschrift für rechtswissenschaftliche Forschung 2010, no. 1, p. 57. See also: K. Günther, "Die symbolisch-expressive Bedeutung der Strafe — Eine neue Straftheorie jenseits von Vergeltung und Prävention?" [in:] Festschrift für Klaus Lüderssen. Zum 70. Geburtstag am 2. Mai 2002, eds. C. Prittwitz et al., Baden-Baden 2002, pp. 205-219.

24 K. Günther, op. cit., pp. 205-219; T. Hörnle, "Die Opferperspektive bei der Strafzumessung," [in:] Die Stellung des Opfers im Strafrechtssystem..., pp. 179-180.

25 Ch. Laue, Symbolische Wiedergutmachung, Berlin 1999; J.K. Lee, Symbolische Wiedergutmachung im strafrechtlichen Sanktionensystem, Frankfurt am Main 2000.

26 M. Tonry, D.P. Farrington, "Strategic approaches to crime prevention," Crime \& Justice 19, 1995, no. 1, pp. 7-10.

27 D.A. Mackey, “Introduction,” [in:] D.A. Mackey, K. Levine, Crime prevention, Burlington 2013, pp. 7-9, 18-20; N. van Ooik, "Prewencja kryminalna w projektowa- 
and their harm resulting from crime is taken with proper seriousness. According to research in the field of criminology, no or too mild a criminal reaction can lead to the erosion of the individual or potential victim's system of values and may even lead them to enter the path of a criminal career (the so-called offender-victim-career). ${ }^{28}$

Based on those remarks, it can be assumed that both individual and potential victims of crime have interests in criminal reaction that include moral and material compensation as well as protection from victimisation in the future. Society is not only a group of potential offenders that should be deterred from committing crimes by, among others, instruments of criminal law, but also a group of potential victims disturbed by information about crimes committed in their neighbourhood and by fear of being victimised in the future in a similar way.

\subsection{Society's interest versus the individual victim's interest in punishment}

One of most common doubts about satisfying the victim's interests with criminal reaction refers to the relationship between interests of the individual victim and society (seen as the potential victim). ${ }^{29}$ Conceptual convergence of their interests in compensation and prevention doesn't mean that their implementation is complementary. While it is usually possible for the offender to compensate, at least to some extent, in a material way, the damage of harm resulting from crime against legal goods of the individual victim, it is most often hardly possible to compensate damage caused in crimes against common goods like the environment or public health. Also moral compensation can be perceived in different ways. The tendency of the individual victim to forgive the offender without additional conditions may even increase society's expectations for his punishment, since he committed an offence to the detriment of a "good

niu przestrzeni," [in:] Mit represyjności albo o znaczeniu prewencji kryminalnej, eds. J. Czapska, H. Kury, Kraków 2002, pp. 527-546.

28 M. Kilchling, "Opferschutz und der Strafanspruch des Staates - ein Widerspruch?," Neue Zeitschrift für Strafrecht 22, 2002, pp. 59-60.

29 K. Seelmann, op. cit., pp. 670-671; Th. Weigend, op. cit., p. 41. 
man" not demanding retribution for unlawfulness caused to him. ${ }^{30}$ Moreover, an offender, to whom the victim is willing to forgive the harm suffered and to give up the demand to punish them, may be convinced that their criminal action does not require any reaction and willing to repeat it, which is against the interests of the community as a potential victim. Individual victims can, on the contrary, demand criminal reaction objectively inadequate to the harm done, which is also contrary to society's interest in just punishment. Different views of the individual and potential victim's interests may also appear in terms of prevention. In jurisprudence of the Court of Justice of the European Union a case appeared where individual victims of domestic violence did not want the court to impose on the offenders the obligation to leave a common place of residence with the victim and restraining order, while a Spanish court considered such measures necessary due to society's interest in protection of victims of domestic violence. The EU-Court of Justice agreed in its decision with the Spanish court. ${ }^{31}$ Such incompatibilities between expectations of the individual and potential victim led to the statement that although satisfying the expectations and interests of the individual victim is a very important aspect of restoring justice, it is the interest of the potential victim in prosecuting the offender in a way that satisfies and protects the whole of society, that should create the lowest limit of penalty imposed. ${ }^{32}$ What punishment is adequate and compatible with society's interests, remains at the court's discretion.

\subsection{Society's interest in criminal proceeding}

Society's interest is not only a term of criminal law, but is also used in criminal proceeding as a factor that may justify the offender's prosecution regardless of the individual victim's will — in Polish literature criminal proceeding was even described as "the fight of the individual

30 M. Moore, "Opfer und Vergeltung: Eine Erwiderung auf George P. Fletcher," [in:] Die Stellung des Opfers im Strafrechtssystem..., p. 95.

31 Judgment of the Court (Fourth Chamber) of 15.9.2011 in joined cases Magatte Gueye (C-483/09) and Valentín Salmerón Sánchez (C-1/10).

32 While the upper limit of penalty is determined by the degree of fault. A. Zoll, “Założenia polityki karnej w projekcie kodeksu karnego," Państwo i Prawo 1994, no 5, p. 7. 
and social interests," supported and protected to different degrees. ${ }^{33}$ Society's interest exists in criminal proceeding next to the "public interest" that justifies intervention of law enforcement authorities if it is required to ensure the proper functioning of the state (for example: notifying initiation of criminal proceeding against public officials to their superiors ${ }^{34}$ ). Society's interest, which seems to be understood wider, is based on the need of protection of common goods ${ }^{35}$ and as such may justify participation of the public prosecutor in private prosecution proceedings ${ }^{36}$ or of a social organisation in any kind of criminal proceeding, if the criminal case refers to statutory tasks of this organisation. ${ }^{37}$ Society's interest can be also derived from the aims of criminal proceeding, which are: detecting the offender of the crime (and not punishing an innocent person), taking into account legitimate interests of the individual victim and respecting their dignity, resolving the criminal case within a reasonable period of time and - equally important from the whole of society's point of view: combating crimes, preventing them and strengthening respect for the law and principles of social coexistence through proper application of measures provided for in penal law and disclosure of circumstances conducive to crime. ${ }^{38}$

It is noticed in the Polish literature that society's interest in prosecuting the offender can be contrary to the will of the individual victim and justify prosecuting an offender even if the victim clearly opposes conduct of criminal proceeding, also in private prosecution cases. ${ }^{39}$ Therefore if

33 M. Cieślak, "Interes społeczny jako czynnik warunkujący prokuratorskie objęcie oskarżenia w sprawie prywatno-skargowej," Państwo i Prawo 1956, no 12, pp. 10501053.

34 Art. $21 \S 2$ of the Polish Code of Criminal Procedure.

35 Like public order or proper functioning of justice system. See: K. Marszał, "Ingerencja prokuratora w sprawy o przestępstwa ścigane z oskarżenia prywatnego w nowym kodeksie postępowania karnego," [in:] Nowe prawo karne procesowe (zagadnienia wybrane). Księga ku czci Profesora Wiesława Daszkiewicza, ed. T. Nowak, Poznań 1999, p. 32.

36 Art. $60 \S 1$ of the Polish Code of Criminal Procedure.

37 Art. $90 \S 1$ of the Polish Code of Criminal Procedure.

38 Art. $2 \S 1$ of the Polish Code of Criminal Procedure.

39 K. Boratyńska, P. Czarnecki, "Commentary to art. 60 of the Polish Code of Criminal Procedure," [in:] Kodeks postepowania karnego. Komentarz, ed. A. Sakowicz, Warszawa 2016, nb 1. 
legal regulations permit discontinuation of criminal proceeding at the request of the individual victim or refrain from imposing a penalty where the individual victim is satisfied with material compensation provided by an offender, an additional condition of such a decision is usually its accordance with the interests of society in moral compensation and prevention (understood as protection from victimisation in the future). Regulations of Polish criminal law require(d) in such cases an accordance of the court decision with the aim of criminal reaction. ${ }^{40}$ Therefore, due to the previously mentioned links between society's interest and aims of criminal law, even if the individual victim is satisfied with the offender's voluntary compensation efforts, society's interest in prosecuting and punishing the offender still remains to be verified. It can speak against discontinuation of the proceeding or resignation from imposing a penalty if, for example, it can be assumed that lack of punishment may induce other people to follow the offender's behaviour. ${ }^{41}$ On the other hand, also the individual victim's interest in material or moral compensation may block the decision of discontinuation of proceeding based on the lack of society's interest, ${ }^{42}$ as in the regulation enabling discontinuation of proceeding in view of the penalty imposed for another offence. ${ }^{43}$

40 According to art. 59 of the Polish Penal Code, if an offence is subject only to imprisonment for up to 3 years, or to a milder type of penalty, and the social impact of the act is not significant, the court may decide to impose a penal measure instead of the penalty, where the aim of penalty can be achieved by penal measure. Art. 59a of the Polish Penal Code (in force from 1.7.2015 to 15.4.2016) enabled to discontinue criminal proceeding at the victim's request, in certain cases, if an offender redressed the damage or compensated for the suffered harm before the start of the trial court proceedings. However this provision did not apply if due to special circumstances the discontinuance of the proceedings would have been inconsistent with the need of achieving the aims of the punishment.

41 The so-called pedagogical purpose of punishment. S. Śliwiński, Polskie prawo karne materialne, Warszawa 1946, pp. 436-437.

42 See: S. Steinborn, "Commentary to Art. 60 of the Polish Code of Criminal Procedure," [in:] Kodeks postępowania karnego. Komentarz do wybranych przepisów, eds. S. Steinborn, J. Grajewski, P. Rogoziński, LEX/el., 2016, nb 6; C. Kulesza, "Ewolucja uprawnień pokrzywdzonego w polskim procesie karnym," [in:] Z problematyki wiktymologii. Księga dedykowana Profesor Ewie Bieńkowskiej, eds. L. Mazowiecka, W. Klaus, A. Tarwacka,Warszawa 2017, p. 84.

43 In accordance with art. 11 of the Polish Code of Criminal Procedure, proceedings concerning a summary offence punishable by a penalty of imprisonment for up to 
Regarding society as a victim of crime with its interests in criminal reaction enables us to create a counterbalance to the interests of the individual victim in criminal law (with respect to the offender's rights and guarantees). Although it is intuitively assumed that criminal law goes beyond extinguishing conflict between the individual victim and offender, it is still not clear what is the additional factor that justifies intervention of criminal law even if there is no individual victim or contrary to their will. The general clause of aims of punishment or society's interest need to be interpreted in accordance with the aims of criminal law. Linking society to these aims defines its position in the criminal case. Society can be seen as a group of potential offenders, but it would not justify prosecution of a detected one. Society can be seen as a neutral third party but then, as a body uninterested in outcomes of crime, it would not have any interest in criminal reaction. Society can also be seen as a potential victim which exists next to or instead of the individual victim. As a victim of crime it is interested in a just reaction to it and protection from further victimisation. Being a potential victim, separated from the individual victim, it may have similar interests in criminal reaction, which are compensation for committed offences and prevention from future victimisation, but in a certain counterbalance to the individual victim's claims. The potential victim with an adequate interest in criminal reaction seems therefore to be the right position for society or at least for a certain community, in regard to criminal reaction.

\section{Interest of society and instruments of criminal law}

\subsection{Instruments of symbolic compensation}

Society as a potential victim is interested in compensation but usually cannot, for practical reasons, be satisfied by settlement with an offender. There are crimes of abstract danger (drinking and driving), crimes based on interference in legal goods of abstract character (possessing drugs or termination of pregnancy) and crimes against common goods

5 years may be discontinued, if the imposition of the penalty on the offender would be obviously purposeless in view of a penalty validly decided for another offence and provided that such a discontinuation is not contrary to the interest of the aggrieved party. 
that mostly ${ }^{44}$ cannot be restored by individuals (environmental pollution). To give the offender chance to compensate such damages to society, German criminal lawyers created a concept of symbolic compensation (symbolische Wiedergutmachung). ${ }^{45}$ The offender's voluntary activity counted to symbolic compensation, should reduce the "bad atmosphere" caused by crime. ${ }^{46}$ It may be achieved by, agreed with the prosecutor, voluntary payment to public benefit institutions, social work for charitable purposes, and even benefits of a personal nature that cannot be legally enforced from an offender (like blood donation). ${ }^{47}$ Due to the fact that such activity is undertaken in ongoing criminal proceeding that causes pressure on the offender, much importance is attached to create limits for the offender's services, such as: prohibition of interference with the essence of fundamental rights and freedoms of the offender, requirement of proportionality or limit of rationality. ${ }^{48}$ Acceptable would be the above mentioned blood donation but transplanting the offender's organs to an unknown recipient would exceed those limits. ${ }^{49}$ The offender's activity within symbolic compensation does not have to be associated with a type of crime, but like a penalty - should be associated with the severity of crime and its

44 Ch. Laue, op. cit., p. 59. However, art. 10.1.b of draft of UN Convention on Justice and Support for Victims of Crime and Abuse of Power (version from 8.2.2010), provides that in cases of environmental crime, State Parties shall legislate to include restitution to restore the environment, reconstruction of the infrastructure, replacement of community facilities and reimbursement of the expenses of relocation, whenever such harm results in the dislocation of the community.

45 J.K. Lee, op. cit., pp. 8-9. See also: H. Schöch, "Vorläufige Ergebnisse der Diskussionen zu einem Alternativ-Entwurf Wiedergutmachung (AE-WGM) im Arbeitskreis deutscher, österreichischer und schweizerischer Strafrechtslehrer," [in:] Neue Wege der Wiedergutmachung im Strafrechts, eds. A. Eser, G. Kaiser, K. Madlener, Freiburg 1990, p. 80; K. Buttig, Die Wiedergutmachung der Folgen einer Straftat, Göttingen 2007, p. 35.

46 Ch. Laue, op. cit., p. 147; D. Frehsee, Schadenswiedergutmachung als Instrument strafrechtlicher Sozialkontrolle, Berlin 1989, p. 168 and following.

47 Ch. Laue, op. cit., pp. 98-100; B.D. Meier, Strafrechtliche Sanktionen, Berlin 2015 , p. 407.

48 Although the significance of symbolic compensation is also noticed at the stage of executing a penalty. J.K. Lee, op. cit., pp. 121-124.

49 H. Schöch, "Strafrecht zwischen Freien und Gleichen im demokratischen Rechtsstaat. Zur konkreten Utopie der Wiedergutmachung im Strafverfahren," [in:] Rechtsstaat und Menschenwürde. Festschrift für Werner Maihofer zum 70. Geburtstag, ed. A. Kaufmann, E.-J. Mestmäcker, H.F. Zacher, Frankfurt am Main 1988, p. 469. 
consequences. However, symbolic compensation recognised as an expression of the offender's critical view of committed crime, is of higher compensation and preventive value than the penalty. ${ }^{50}$ Despite the indicated advantages, the concept of symbolic compensation has not been regulated in neither German nor Polish criminal law, but voluntary efforts of an offender to satisfy society (or a certain community) before or during the criminal proceeding is seen as a circumstance which should be "taken into account" in course of the proceeding. ${ }^{51}$

\subsection{Community sanctions and measures}

Society's interest in compensation and prevention can also be satisfied with an alternative reaction to crime than penalty based on imprisonment. The above mentioned Recommendation Rec (2017) 3 on the European Rules on community sanctions and measures, describes the advantages of such instruments as maintaining suspects or offenders in the community, where they are subject to some restrictions on their liberty through the imposition of certain conditions and (or) obligations. Community sanctions and measures are instruments imposed by a judicial or administrative authority, before or instead of the decision on sanction; they may also serve enforcing sentence of imprisonment outside the prison establishment. Examples of such instruments are given, among others: probation or community supervision as an independent sanction imposed without pronouncement of a sentence to imprisonment, suspension of the enforcement of a sentence to imprisonment with imposed conditions, community service (understood as unpaid work on behalf of the community), restriction on the freedom of movement, electronic monitoring (administered in accordance with CM/Rec (2014) 4) or treatment orders for drug or alcohol misuse by offenders and those suffering from mental illness related to their criminal behaviour. ${ }^{52}$ These instruments, applied on the assumption that the protection of society does not require isolation of an offender, still create a wide range of sanctions and measures focusing on elimination of an actual source of danger (drug or alcohol misuse, driving vehicles, con-

50 See: J.K. Lee, op. cit., p. 118; Ch. Laue, op. cit., pp. 16-17.

51 J.K. Lee, op. cit., p. 25.

52 Explanatory memorandum to the recommendation, pp. 4-5. 
tact with a certain person or environment, work in a certain profession), without excessive interference in the rights and freedoms of individuals, both: offenders and individual victims. Such a solution shows that criminal sanction may respond to the sense of justice and security without isolating an offender from the community and causing stigmatisation that may hinder his return to society after serving a sentence. Instruments of this kind exist in Polish law where they are defined as criminal or probation measures, as well as in German law. ${ }^{53}$ Specific for Polish law is, however, the rapid increase in the amount of types of such measures, ${ }^{54}$ introduced not only to the Penal Code but regulated also in other acts of law. In 2005 a group of community sanctions and measures in the Polish Penal Code from 1997, including deprivation of public rights (art. 39 p. 1 PC), prohibition from occupying a specific position, practising a specific profession or operating a specific business (art. 39 p. 2 PC) and prohibition from operating vehicles (art. 39 p. 3 PC), was supplemented with prohibition from operating activities related to nurturing, treating, educating minors or taking care of them (art. 39 p. 2a PC) and prohibition from associating with specific social groups or appearing in specific locations, contacting certain individuals or leaving a specific place of stay without the court's consent (art. 39 p. 2b PC). In 2009 prohibition from entering a mass event was introduced (art. 39 p. 2c PC) and in 2010 the Polish Penal Code was supplemented by prohibition from approaching certain individuals (introduced into art. 39 p. 2b PC) prohibition from entering gambling facilities and engaging in gambling (art. 39 p. 2d PC) and an order to leave, for a determined period of time, the premises occupied together with a victim (art. 39 p. 2e PC). Moreover in 2010 the Polish Parliament introduced,

53 Among others: parole suspension on probation (Strafaussetzung zur Bewährung, $\S 56$ of the German Penal Code), warning with penalty (Verwarnung mit Strafvorbehalt, $\S 59$ of the German Penal Code), diversion measures (Diversionmaßnahmen). See: W. Heinz, Das strafrechtliche Sanktionensystem und die Sanktionierungspraxis in Deutschland 1882-2006, Konstanz 2008, pp. 30, 42; H. Schöch, "Restorative Justice in Deutschland und Europa," [in:] Scripta amicitiae. Freundschaftsgabe für Albin Eser zum 80. Geburtstag am 26. Januar 2015, eds. B. Burkhardt et al., Berlin 2015, p. 190.

54 More on this topic: E. Hryniewicz-Lach, "Ograniczenie praw obywatelskich i politycznych jako przedmiot sankcji karnej," [in:] Współczesne przekształcenia sankcji karnych — zagadnienia teorii, wyktadni i praktyki stosowania, eds. P. Góralski, A. Muszyńska, Warszawa 2018, pp. 209-229. 
out of the Penal Code, permanent withdrawal of a fishing or spearfishing card or its transfer to a court deposit for a period not less than 12 months, until submission of a second positive exam, and in 2012 out of the Penal Code — prohibition from possessing animals. ${ }^{55}$

\section{Influence of European criminal law on Polish penal law}

The increase in legal regulations based on prevention in Polish penal law between 2005 and 2012 can be associated with two important factors. The same factors seem to regulate the influence of European criminal law on the Polish system of criminal law. The first is the degree of binding of Poland by European law regulations. If Poland is formally obliged to introduce certain regulations into the Polish legal system (like EU-directives), it will happen without further justification. If the regulation is of a facultative character (like Council of Europe recommendations), its introduction to the Polish legal system depends on the second factor: whether its introduction may be seen as necessary and proportional in supporting protected legal goods. Since all state interference with rights and freedoms of individuals must be consistent with the requirements of its necessity and proportionality, introduction of every new instrument into criminal law should be properly justified (ultima ratio principle). ${ }^{56}$ Necessity requirement ${ }^{57}$ is associated with the protection of essential individual and common values and hereby with the individual and potential victim's interest in prevention and compensation. ${ }^{58}$ The proportionality requirement refers

55 Art. 35 of the Polish law on protection of animals (ustawa z 21 sierpnia 1997 roku o ochronie zwierząt, tekst jedn. Dz.U. z 2017 r., poz. 1840), art. 27c of the Polish law on inland fishing (ustawa z 18 kwietnia 1985 roku o rybactwie śródlądowym, tekst jedn. Dz.U. z 2015 r., poz. 652).

56 K. Wojtyczek, "Zasada proporcjonalności jako granica prawa karania," Czasopismo Prawa Karnego i Nauk Penalnych 1999, no. 2, pp. 31-51; S. Żółtek, Prawo karne gospodarcze w aspekcie zasady subsydiarności, Warszawa 2009, pp. 248-290.

57 Determined also as two separate requirements: requirement of usefulness and of necessity. See: K. Wojtyczek, op. cit., pp. 34-40.

58 See: E. Hryniewicz-Lach, Ofiara $w$ polskim prawie karnym. Interesy ofiary przestepstwa i karno-materialne instrumenty stuzace ich zabezpieczeniu, Warszawa 2017, pp. 164-172. 
to the scope of justified interference in the offender's rights and freedoms ${ }^{59}$ and determines what can be expected from an offender. ${ }^{60}$

In Polish criminal law based mainly on the concept of crime prevention, moral compensation, associated with revenge on the offender, is not seen as proper justification for criminal sanctions. Therefore the (individual and potential) victim's interest in compensation is supported principally in cases of material compensation and voluntary offender's activity for the individual victim. Prevention is, instead, a generally acceptable justification for use of criminal law instruments. Since the raising of statutory penalty limits is seen as a populist and ineffective method of controlling crime, prevention activity in criminal law is mainly based on removing the opportunity to commit crimes by eliminating circumstances in which a crime was or may be committed. In consequence, if Parliament (and the current ruling party) wants to be seen as involved in limiting the number of crimes, it justifies its activities by preventive purpose. Therefore the above mentioned community sanctions and measures introduced into the Polish Penal Code in 2005-2012 were justified on preventive grounds. ${ }^{61}$

\section{Conclusions}

The remarks presented above regarding society as a victim of crime lead to the following conclusions:

1. It is noticed in European criminal law, including directives of the European Union, recommendations of the Council of Europe and declaration of the United Nations on basic principles of justice for victims of crime (and abuse of power), that crimes are committed not only against individual victims but also against society (at large or against a certain community).

2. The position of society as a potential victim (in contrast to individual victim) is justified by the nature of its interests in criminal response. Those

59 K. Wojtyczek, op. cit., pp. 41-46. J. Zakolska, Zasada proporcjonalności w orzecznictwie Trybunału Konstytucyjnego, Warszawa 2008, pp. 27-31.

60 E. Hryniewicz-Lach, op. cit., pp. 172-179.

61 Critically in this regard: W. Wróbel, "Środek karny zakazu wstępu na imprezę masową,” [in:] Kary i inne środki reakcji karnej. System Prawa Karnego, vol. 6, ed. M. Melezini, Warszawa 2016, p. 641. 
interests, which can be associated with the aims of criminal law (defined here as restoring a sense of security and justice, disturbed by an offence), include: moral compensation (supplemented by material compensation by individual victims) and prevention from victimisation in the future.

3. The need to pay attention to the interests of society in response to a crime is indicated, in European criminal law, by propositions of instruments which can bring some benefits to the community in the compensation and protection field. Such instruments, defined as community sanctions and measures, focus on the offender's activity to satisfy individual and potential victims and on elimination of the identified source of danger in order to protect them.

4. Regarding society as a victim enables us to see criminal reaction in broader context, going beyond the interests of individuals and creating a counterweight to them. This allows us to see why the victim-offender-settlement can be seen as insufficient to achieve the aims of criminal law and justify conducting criminal proceedings even against the individual victim's will.

5. Criminal reaction based of satisfying society's interests may be seen as an important and developing field of criminal law, but in an appropriate relation to the individual victim's interest and procedural guarantees of an offender. To achieve the aims of criminal law, society (or the community) should be seen as a relevant subject on the victim's side and not (only) as a potential offender or neutral third party providing services in the field of criminal law.

6. Legal instruments that should satisfy the needs of society in response to crime develop in Polish law in a specific way. While the number of instruments based, in principle, on prevention is growing rapidly, the concept of moral compensation to society with other instruments as a penalty, is rarely discussed and mainly in the context of the German theoretical concept of symbolic compensation.

7. The influence of European criminal law on the Polish system of criminal law is generally based on two aspects: (I.) whether introducing certain regulation(s) is obligatory (EU-directives) or facultative (Council of Europe recommendations) and (II.) whether the proposed solutions are necessary and proportional to support protected legal goods (ultima ratio principle). The necessity requirement refers to the protection of essential 
individual and common values and hereby to the individual and potential victim's interest in prevention and compensation. The proportionality requirement refers to the scope of justified interference in the offender's rights and freedoms, determining what can be expected from an offender.

8. The victim's interest in compensation in Polish criminal law is supported principally in cases of material compensation and voluntary offender's activity for the individual victim. Prevention is, instead, a generally acceptable justification for use of criminal law instruments and is based mainly on removing the opportunity to commit crimes by eliminating circumstances in which a crime was or may be committed.

\section{References}

Boratyńska K., Czarnecki P., „Komentarz do art. 60 k.p.k.” [in:] Kodeks postępowania karnego. Komentarz, ed. A. Sakowicz, Warszawa 2016.

Buttig K., Die Wiedergutmachung der Folgen einer Straftat, Göttingen 2007.

Chlebowicz P., Samosad we Wtodowie. Studium przypadku, Olsztyn 2017.

Cieślak M., "Interes społeczny jako czynnik warunkujący prokuratorskie objęcie oskarżenia w sprawie prywatno-skargowej," Państwo i Prawo 1956, no. 12.

Czapska J., Bezpieczeństwo obywateli. Studium z zakresu polityki prawa, Kraków 2004. Eser A., Walther S., Wiedergutmachung im Kriminalstrafrecht. Internationale Perspektiven, Vol. 1-3, Freiburg-Breisgau 1996-2001.

Feinberg J., "Funkcja ekspresyjna kary kryminalnej," Ius et Lex 2006, no. 1.

Fletcher G.P., "Der Platz des Opfers in einer Vergeltungstheorie," [in:] Die Stellung des Opfers im Strafrechtssystem. Neue Entwicklungen in Deutschland und in den USA, ed. B. Schünemann, M.D. Dubber, Köln-München 2000.

Frehsee D., Schadenswiedergutmachung als Instrument strafrechtlicher Sozialkontrolle, Berlin 1989.

Günther K., "Die symbolisch-expressive Bedeutung der Strafe - Eine neue Straftheorie jenseits von Vergeltung und Prävention?" [in:] Festschrift für Klaus Lüderssen. Zum 70. Geburtstag am 2. Mai 2002, eds. C. Prittwitz et al., Baden-Baden 2002.

Hassemer W., "Warum und zu welchem Ende strafen wir?” Zeitschrift für Rechtspolitik 1997.

Hörnle T., "Die Opferperspektive bei der Strafzumessung,” [in:] Die Stellung des Opfers im Strafrechtssystem. Neue Entwicklungen in Deutschland und in den USA, ed. B. Schünemann, Köln-München 2000.

Hryniewicz-Lach E., Ofiara w polskim prawie karnym. Interesy ofiary przestępstwa i karno-materialne instrumenty stużace ich zabezpieczeniu, Warszawa 2017.

Hryniewicz-Lach E., "Ograniczenie praw obywatelskich i politycznych jako przedmiot sankcji karnej," [in:] Wspótczesne przekształcenia sankcji karnych — zagadnienia 
teorii, wykładni i praktyki stosowania, eds. P. Góralski, A. Muszyńska, Warszawa 2018.

Kilchling M., "Opferschutz und der Strafanspruch des Staates — Ein Widerspruch?" Neue Zeitschrift für Strafrecht 22, 2002.

Kossowska A., "Sytuacyjne zapobieganie przestępczości," Archiwum Kryminologii 20, 1994.

Kulesza C., "Ewolucja uprawnień pokrzywdzonego w polskim procesie karnym,” [in:] Z problematyki wiktymologii. Księga dedykowana Profesor Ewie Bieńkowskiej, ed. L. Mazowiecka, W. Klaus, A. Tarwacka,Warszawa 2017.

Laue Ch., Symbolische Wiedergutmachung, Berlin 1999.

Lee J.K., Symbolische Wiedergutmachung im strafrechtlichen Sanktionensystem, Frankfurt am Main 2000.

Mackey D.A., "Introduction to crime prevention," [in:] Crime prevention, eds. D.A. Mackey, K. Levine, Burlington 2013.

Marquardt H., "O teoretycznym i praktycznym znaczeniu celów kary w zachodnio-niemieckim prawie karnym," [in:] Teoretyczne problemy odpowiedzialności karnej w polskim oraz niemieckim prawie karnym. Materiały Polsko-Niemieckiego Sympozjum Prawa Karnego, ed. T. Kaczmarek, Karpacz 1990.

Marszał K., "Ingerencja prokuratora w sprawy o przestępstwa ścigane z oskarżenia prywatnego w nowym kodeksie postępowania karnego," [in:] Nowe prawo karne procesowe (zagadnienia wybrane). Księga ku czci Profesora Wiesława Daszkiewicza, ed. T. Nowak, Poznań 1999.

Meier B.D., Strafrechtliche Sanktionen, Berlin 2015.

Moore M., "Opfer und Vergeltung: Eine Erwiderung auf George P. Fletcher," [in:] Die Stellung des Opfers im Strafrechtssystem. Neue Entwicklungen in Deutschland und in den USA, eds. B. Schünemann, M.D. Dubber, Köln-München 2000.

Neue Wege der Wiedergutmachung im Strafrecht, ed. A. Eser, G. Kaiser, K. Madlener, Freiburg-Breisgau 1992.

Ooik N. van, "Prewencja kryminalna w projektowaniu przestrzeni," [in:] Mit represyjności albo o znaczeniu prewencji kryminalnej, ed. J. Czapska, H. Kury, Kraków 2002.

Reemtsma J.Ph., Das Recht des Opfers auf die Bestrafung des Täters - als Problem. Schriften der Juristischen Studiengesellschaft Regensburg, München 1999.

Roxin C., "Nowe kierunki polityki kryminalnej," Przegląd Prawa Karnego 1990, no. 4. Schmidt-Hieber W., "Ausgleich statt Geldstrafe," Neue Juristische Wochenschrift 1992. Schöch H., "Restorative Justice in Deutschland und Europa," [in:] Scripta amicitiae. Freundschaftsgabe für Albin Eser zum 80. Geburtstag am 26. Januar 2015, eds. B. Burkhardt et al., Berlin 2015.

Schöch H., "Strafrecht zwischen Freien und Gleichen im demokratischen Rechtsstaat. Zur konkreten Utopie der Wiedergutmachung im Strafverfahren," [in:] Rechtsstaat und Menschenwürde. Festschrift für Werner Maihofer zum 70. Geburtstag, eds. A. Kaufmann, E.-J. Mestmäcker, H.F. Zacher, Frankfurt am Main 1988.

Schöch H., "Vorläufige Ergebnisse der Diskussionen zu einem Alternativ-Entwurf Wiedergutmachung (AE-WGM) im Arbeitskreis deutscher, österreichischer und 
schweizerischer Strafrechtslehrer," [in:] Neue Wege der Wiedergutmachung im Strafrechts, eds. A. Eser, G. Kaiser, K. Madlener, Freiburg 1990.

Seelmann K., "Paradoxien der Opferorientierung im Strafrecht," JuristenZeitung 1989.

Smarzewski M., Podmiot bierny przestępstwa na tle włoskiego prawa karnego, Lublin 2013.

Steinborn S., "Commentary to Art. $11 \mathrm{KPK}, \mathrm{Nb} 6$," [in:] Kodeks postępowania karnego. Komentarz do wybranych przepisów, eds. S. Steinborn, J. Grajewski, P. Rogoziński, LEX/el., 2016.

Śliwiński S., Polskie prawo karne materialne, Warszawa 1946.

Tonry M., Farrington D.P., "Strategic approaches to crime prevention," Crime \& Justice 19,1995 , no. 1 .

Weigend Th., "Die Strafe für das Opfer?" — Zur Renaissance des Genugtuungsgedankens im Straf- und Strafverfahrensrecht," Zeitschrift für rechtswissenschaftliche Forschung 2010, no. 1.

Wojtyczek K., "Zasada proporcjonalności jako granica prawa karania," Czasopismo Prawa Karnego i Nauk Penalnych 1999, no. 2.

Wróbel W., "Środek karny zakazu wstępu na imprezę masową," [in:] Kary i inne środki reakcji karnej. System Prawa Karnego, vol. 6, ed. M. Melezini, Warszawa 2016.

Zakolska J., Zasada proporcjonalności w orzecznictwie Trybunału Konstytucyjnego, Warszawa 2008.

Zehr H., Gohar A., The little book of restorative justice, 2003 https://www.unicef.org/ tdad/ littlebookrjpakaf.pdf (accessed: 18.11.2019).

Żółtek S., Prawo karne gospodarcze w aspekcie zasady subsydiarności, Warszawa 2009.

\section{Summary}

Crimes committed against individual victims quite often affect the whole of society or a certain community as well. Therefore society should be seen as a relevant subject on the victim's side, and not only as a potential offender or a neutral third party providing certain services for individual victims. Regarding society as a kind of a victim enables us to see crime and criminal reaction in a broader context going beyond the interests of individuals and creating a counterweight to them. For this reason it is important to see in which way society can be victimised, what are its preventive and compensatory interests and how they can be satisfied with the instruments of criminal law.

Keywords: Victim, compensation, prevention, criminal law 